\title{
PENDAMPING BELAJAR ATAU GURU BARU? FENOMENA AKTIFITAS IBU DALAM PROSES BDR SISWA SD MASA PANDEMI COVID 19
}

\author{
Sukma Erni ${ }^{1}$, Yasnel $^{2}$, Elya Roza $^{3}$, Melfa Yola, ${ }^{4}$ Salmiah $^{5}$ \\ Universitas Islam Negeri Sultan Syarif Kasim Riau, Indonesia \\ ${ }^{1}$ sukma.erni@uin-suska.ac.id \\ 2yasnel@suska.ac.id \\ 3elya.roza@uin-suska.ac.id \\ ${ }^{4}$ melfa.yola@uin-suska.ac.id \\ 5salmiah@uin-suska.ac.id
}

\begin{abstract}
The Home Learning Program (BDR), which must be implemented due to the COVID-19 pandemic, directly increases the workload of mothers as learning companions for children to replace teachers' duties. Apart from the facilities used, the difficulties found were related to the division of working time between household work. and child assistance, difficulties with children's learning materials, disciplining children to learn. The impact is that learning assistance only becomes a side activity after completing household chores. The difficulties faced by mothers cannot be separated from the level of education, communication between parents and schools (teachers) and the double burden of mothers in household affairs.
\end{abstract}

Keywords : BDR, the Covid Pandemic, Educational empowerment, Double Burden, Learning Assistance,

\section{ABSTRAK}

Program Belajar Dari Rumah (BDR) yang harus dilaksanakan akibat pendemi covid 19 secara langsung menambah beban kerja ibu sebagai pendamping belajar anak menggantikan tugas guru. Selain fasilitas yang digunakan, kesulitan yang ditemukan terkait dengan pembagian waktu kerja antara kerja rumah tangga dan pendampingan anak, kesulitan materi belajar anak, mendisiplinkan anak untuk belajar. Dampaknya pendampingan belajar hanya menjadi kegiatan sambilan setelah meneyelesaikan pekerjaan rumah tangga. Kesulitan yang dihadapi ibu tidak terlepas dari tingkat Pendidikan, komunikasi orang tua dan sekolah (guru) dan beban ganda ibu dalam urusan rumah tangga.

Kata Kunci : Beban Ganda, BDR, Keberdayaan Pendidikan, Pandemi Covid, Pendampingan Belajar 


\section{PENDAHULUAN}

Ibu adalah segmen social dalam keluarga dan masyarakat yang memegang peranan penting dalam banyak hal. Bukan hanya terkait urusan rumah tangga, keberlangsungan proses kehidupan makan dan minum, sanitasi dan kesehatan keluarga tetapi lebih jauh sampai pada aspek ekonomi, social, Pendidikan dan lain sebagainya. Dalam realitas sosial, banyak ditemukan ibu yang memiliki perna ganda domestic dan public. Selain peran dosmetik sebagai seorang istri, ibu dan pengelola rumah tangga, ibu juga bekerja untuk tujuan ekonomi di luar rumah. Kendati peran social tersebut merupakan pilihan (Tanenji:2012) banyak ibu dalam kaitan ini melaksanakan peran ganda sehingga menanggung multi beban. Terdapat ibu yang menghabiskan waktu bekerja untuk memenuhi kebutuhan ekonomi lebih dari 12 jam perhari sehingga waktu pengelolaan rumah tangga sekaligus sebagai ibu dan istri jauh lebih pendek (Suhertina, Darni;. 2018).

Masa pandemic covid 19, rutinitas ibu baik yang bekerja di luar rumah ataupun yang hanya mengerjakan pekerjaan domestic bergeser sedemikian rupa. Ritme kerja dan alokasi waktu yang diberikan mau tidak mau di tata ulang agar semua urusan terselesaikan. Berawal dari mewabah di Wuhan Cina, virus ini dengan cepat meluas keseluruh penjuru dunia termasuk Indonesia. Di Indonesia sendiri, 15 Maret 2020 merupakan titik awal dari meluasnya wabah menjamah semua lini di tengah masyarakat. Kendati sejak awal tahun fenomenanya sudah dijumpai di kota-kota besar, namun pada bulan Maret tersebut adalah puncak "shock" warga dengan hamper meratanya serangan wabah di negeri ini.

Semua aktifitas dikembalikan ke rumah, bekerja dari rumah, belajar-sekolah dari rumah sehingga rumah yang semula bermakna tempat istirahat berubah menjadi tempat bekerja sekaligus tempat belajar- semi sekolah (erni : 2020). Dapat dibayangkan betapa 'crowded'nya rumah dalam waktu sekejap mata, tanpa ada persiapan ataupu aba-aba sebelumnya, rumah memegang peran penting lainnya yang semula lebih santai menjadi seirus sekaligus santai. Tugas-tugas ibu yang semula lebih santai dipaksa untuk mengatur ulang jam kerja karena bertambahnya tugas lain baik pekerjaan yang semula di luar rumah dan beban pendampingan belajar anak.

Harus diakui bahwa pandemic covid 19 bukanlah sembarang wabah yang dapat dianggap sepele. Data menunjukkan bahwa jutaan manusia telah menjadi korban di seluruh dunia. Terdata 12,1 juta jiwa korban covid diseluruh dunia, per tanggal 8 Juli 2020, (worldmeters.info, kabar 24 Bisnis.com). Data tersebut termasuk Indonesia yang nota bene per 15 September 2020 mengalami peningkatan signifikan menjadi 225.030 orang (merdeka.com). dengan demikian dipastikan bahwa dalam rentang 6 bulan mulai 15 maret-15 
Vol. 19, No. 2, 2020, Hal. 108 - 120

september 2020, terdapat 225.030 penduduk Indonesia yang terkena Covid 19. Kondisi demikian secara tidak langsung meningkatkan kewas-wasan orang tua terutama ibu dengan kesehatan keluarganya. Anak usia sekolah terutama SD dalam hal ini menjadi perhatian penuh karena pola pengaturan waktu antara belajar dan bermain selama ini terpisah antara sekolah di luar rumah dengan waktu di rumah menjadi menyatu di dalam rumah. Fenomena ini tidak terlepas dari kemanjaan anak usia SD pada ibunya di rumah, kecenderungan untuk bermain, santai dan tidak disipilin waktu berubah menjadi situasi yang dipenuhi dengan kegiatan sekolah, tugas dll. Tugas multi beban yang selama ini dihadapi ibu bertambah dengan keharusan mendampingi dan mengajar anak usia SD di rumah dengan segala kecenderungan anak yang sudah terbangun selama ini.

Pendampingan pembelajaran anak usia SD hakikatnya tidak jauh berbeda dengan mengajar anak kendati tempatnya di rumah. Pola belajar anak yang menggunakan pendekatan perorangan di sekolah yang diperankan oleh guru berubah diperankan oleh ibu. Kedekatan ibu dan anak dalam hal ini menjadi peluang utama dalam mengoptimalkan proses pembelajaran anak di rumah. Ibu sebagai pengasuh utama anak (Berns:2007) senantiasa berada dekat dan memberikan perhatian penuh pada kegiatan anak (Mallers, Neupert, Charles \& Almeida, 2010). Kurangnya perhatian orang tua justru akan berdampak tidak hanya pada perilaku belajar anak tetapi juga kenakalan yang akan berdampak buruk pada anak (Santrock: 2011).

Secara social, peran ibu lebih banyak pada area domestic. Mengurus segala sesuatu berkaitan dengan rumah, penyediaan makanan anggota keluarga, pembersihan, penataan termasuk pantauan interaksi social anggota keluarga terutama antara anak; kakak,adik dan abang (Fakih:2008). Peran yang diturunkan dari generasi ke generasi menjadi status social ibu rumah tangga, atau pun sebutan 'orang rumah' (Budiman, dalam Abdullah:1997) melekat pada perempuan kendati sebagian perempuan memilih untuk bekerja juga di luar rumah. Situasi beban social perempuan, bekerja di luar rumah tentu semakin tinggi dengan adanya pekerjaan lain yang harus dikerjakan dengan serius. Dalam keadaan ini, ketika pandemic terjadi dan semua atau sebagain besar kegiatan dilaksanakan dari rumah, demikian juga dengan kegiatan belajar (sekolah) anak maka situasi dan beban social ibu semakin menumpuk. Penelitian ini hakikatnya mendeskripsikan fenomena situasi yang dihadapi ibu ketika harus mendampingi anak usia sekolah dasar dalam proses belajar dari rumah.

Kegiatan belajar dari rumah adalah kegiatan alternative pemenuhan hak pendidikan anak ketika terjadi pandemic covid 19. Dalam sejarah pendidkan Indonesia, kegiatan belajar dari rumah sebagai pengganti sekolah ini belum pernah terjadi. Menghadapi situasi darurat 
Vol. 19, No. 2, 2020, Hal. 108 - 120

ini, pemerintah akhirnya mengeluarkan Surat edaran No. 15 tahun 2020 tentang Pedoman Penyelennggaraan Belajar dari Rumah. Pada prinsipnya surat edaran ini mengharuskan penyelenggaraan Pendidikan di sekolah ke rumah. Dengan adanya edaran terkait maka proses pembelajaran tetap akan berjalan. Terdapat beberapa point yang menjadi tugas orang tua dalam kegiatan belajar dari rumah yakni : 1) Menyepakati cara untuk berkomunikasi dengan pihak sekolah, 2) mendiskusikan rencana pembelajaran yang inklusif Bersama guru sesuai kondisi anak didik, 3) Menyiapkan perangkat pembelajaran, 4) Memastikan peserta didik siap untuk mengikuti pembelajaran, 5) Menyiapkan waktu untuk mendukung proses pembelajaran daring, 6) Mendorong anak agar aktif selama proses pembelajaran, 7) Orang tua/wali memastikan anak mengisi lembar aktifitas sesuai dengan bahan pemantauan belajar harian, 8) Mengumpulkan foto lembar aktifitas dan penugasan setiap hari, 9) Secara aktif berdiskusi dengan guru terkait tantangan dan kendala yang dihadapi selama proses pembelajaran daring, 10) Memastikan tempat dan fasilitas belajar nyaman (Pedoman Pelaksanaan BDR selama darurat bencana covid 19 di Indonesia : SE No 15 tahun 2020)

Dalam pelaksanaan Pendidikan dengan pola belajar dari rumah (BDR) tidaklah sederhana dan mudah dilaksanakan. Banyak aspek yang terkait dengan proses tersebut, selain sarana pra sarana, sumberdaya anggota rumah dalam kait ini ibu akan menjadi sumberdaya yang paling dekat dengan proses pendampingan belajar dari rumah yang harus berjalan. Peran pendamping akan berjalan seiring dengan peran guru dalam proses pembelajaran agar capain pembelajaran yang diinginkan dapat diperoleh dengan baik.

\section{METODE PENELITIAN}

Penelitiaan ini adalah survey pada 33 orang ibu yang memiliki anak pada tingkat SD di 3 kabupaten Kota yakni; Kota Pekanbaru, Kabupaten Kampar dan kabupaten Bengkalis. Sampel ditarik merupakan sampel partisipan yakni yang bersedia memberikan informasi tentang pendampingan pembelajaran dari rumah yang dilaksanakannya. Responden penelitian berasal dari latar belakang pendidikan dan tingkat ekonomi beragam. Data diperoleh melalui wawancara meliputi antara laini, waktu pendampingan, pembagan waktu kerja, kesulitan yang dihadapi terarah, dilaksanakan secara online melalui telpon, video call maupun voice note. Data terkumpul dipetakan sesuai dengan temuan yang ada dan dianalisis secara deskriptif. 


\section{HASIL DAN PEMBAHASAN}

Proses pembelajaran yang dilaksanakan dari rumah hakikatnya bukan hal yang mudah. Data responden yang melibatkan ibu rumah tangga, ibu yang bekerja di dunia public dan nenek (pengasuh siswa) yang harus mengambil alih tugas pembelajaran yang selama ini dilaksanakan di sekolah. Pelibatan orang tua sebagai pendamping belajar dirasakan menjadi beban tambahan disamping beban lain yang harus dikerjakan. Dampak yang tidak bisa ditolak adalah munculnya ketegangan anak dan orang tua, anak merasa terbeban dengan setumpukan tugas belajar di rumah dan orang tua sulit membagi waktu, terpaksa belajar ulang, terkadang kesal dengan perilaku anak sehingga agak emosional, anak menjadi tidak focus, lebih mengandalkan google, membiarkan tugas sehingga orang tua terpaksa mengerjakan tugas yang diberikan dan lain sebagainya.

Kendati demikian dari seluruh responden yang terlibat mengatakan telah melakukan pendampingan pada waktu anak belajar. Yang menarik adalah, sebagian besar responden mengatakan bahwa membantu anak mengerjakan tugas yang diberikan dari sekolah. Dengan latar belakang Pendidikan yang beragam, ibu ataupun nenek terpaksa membantu menemani mengerjakan tugas siswa dengan segala kerumitan yang ada. Terdapat beberapa responden yang menyebutkan mereka hanya menemani saja, bertanya apakah tugas sudah selesai, ketika siwa mengeluh tidak memehami tugas dengan baik mereka hanya meminta anak untuk bertanya pada guru atupun teman sekelasnya.

Tabel 1.Data responden

\begin{tabular}{|l|l|l|l|l|}
\hline No & Pendamping & Pekerjaan & Pendidikan & Jumlah \\
\hline 1 & Nenek/pembantu & Ibu rumah Tangga & SMP/MTs & 2 \\
\hline 2 & Ibu /kakak & $\begin{array}{l}\text { Ibu rumah tangga/ } \\
\text { siswa }\end{array}$ & $\begin{array}{l}\text { Tidak tamat } \\
\text { SMU }\end{array}$ & 9 \\
\hline 3 & Ibu & Ibu rumah tangga & SMU & 10 \\
\hline 4 & Ibu & Bekerja di luar rumah & SMU1 & 3 \\
\hline 5 & Ibu /orang tua & Bekerja di luar rumah & Sarjana & 6 \\
\hline 6 & Guru les & Bekerja & Sarjana & 3 \\
\hline \multicolumn{2}{|c|}{ Jumlah } & 33 \\
\hline
\end{tabular}

Pola pendampingan yang dilaksanakan sangat beragam, ada justru yang mengatakan bahwa bukan hanya membimbing tetapi juga mengajar sebagaimana yang dilaksanakan guru disekolah. Demikian pula dengan waktu pendampingan yang dilaksanakan. Keberagaman pola dan waktu pendampingan ini dapat dilihat dalam tabel 2 : 
Tabel 2.Bentuk dan waktu pendampingan proses Belajar dari Rumah

\begin{tabular}{|c|c|c|c|}
\hline No & $\begin{array}{c}\text { Kegiatan } \\
\text { pendampingan }\end{array}$ & Waktu Pendampingan & Pendamping \\
\hline 1. & Menemani saja & $\begin{array}{l}\text { Kapan anak merasa mood belajar. Dianjurkan segera } \\
\text { tetapi jika tidak mau maka akan mengikuti kapan } \\
\text { anak akan belajar. }\end{array}$ & $\begin{array}{l}\text { Nenek, } \\
\text { Pembantu }\end{array}$ \\
\hline 2 & $\begin{array}{l}\text { Menemani dan } \\
\text { Membimbing }\end{array}$ & $\begin{array}{l}\text { Sepulang kerja, sesuai dengan jadwal mata } \\
\text { pelajaran yang ada, setelah selesai pekerjaan rumah }\end{array}$ & Ibu \\
\hline 3 & $\begin{array}{l}\text { Menemani, } \\
\text { menunjukkan }\end{array}$ & $\begin{array}{l}\text { Sesuai dengan jadwal pelajaran, ketika tugas sudah } \\
\text { dikirim }\end{array}$ & Ibu, kakak \\
\hline 4 & $\begin{array}{l}\text { Membantu } \\
\text { menyelesaikan }\end{array}$ & Sesuai dengan waktu yang diminta & Ibu, kakak \\
\hline 5 & $\begin{array}{l}\text { Menemani dan } \\
\text { membantu sambil } \\
\text { mengerjakan } \\
\text { pekerjaan rumah }\end{array}$ & Sesuai dengan waktu yag ditentukan guru & Ibu \\
\hline 6 & $\begin{array}{l}\text { Membimbing } \\
\text { sambil bekerja }\end{array}$ & $\begin{array}{l}\text { Sesuai situasi, ketika WFH bisa langsung } \\
\text { membimbing dan ketika WFO via telp dan disela } \\
\text { waktu senggang kerja }\end{array}$ & Ibu \\
\hline 7 & $\begin{array}{l}\text { Menemani, } \\
\text { membimbing dan } \\
\text { mengajar }\end{array}$ & Sesuai waktu yang diminta dari sekolah & Ibu \\
\hline
\end{tabular}

Dalam tabel 2 diatas, tampak bahwa proses pendampingan sangat beragam. Tidak semua perempuan pendamping belajar anak tingkat sekolah dasar mendampingi proses belajar dengan baik. Katakanlah bahwa sebelum mengerjakan tugas yang diberikan dari sekolah, anak diminta untuk mempelajari informasi materi pembelajaran yang diberikan terlebih dahulu. Memahami materi dengan baik, mencobakan, menuliskan ulang ataupun menceritakan kembali hasil bacaannya. Sebagian ibu mengatakan bahwa anak sudah diminta untuk membaca, memahami, dan mencoba menceritakan kembali bahan yang sudah dibaca, namun sering sekali "mandeg" karena anak terburu-buru. Mengerjakan tugas secepat mungkin agar selesai dan kembali bisa bermain. Dalam keadaan ini, anak akan malas, merajuk dan terkesan marah bila "ditahan" untuk membaca kembali, menuliskan bacaan dan menjawab pertanyaan.

Disisi lain pendamping yang hanya menemani, tidak banyak berbuat selain menungui sampai selesai tugas dikerjakan. Belajar yang hanya ditemani, anak yang diminta berinisiatif sendiri jika menghadapi kesulitan dengan cara mengontak teman atau guru. Ketika anak 
merasa selesai tanpa harus dicek, ditanya dan perhatikan kesiapan belajar, amak sudah boleh menghentikan kegiatan belajar.

Mendampingi dan membimbing dilaksanakan bila anak merasa ada kesulitan. Harus diakui tidak semua ibu/ perempuan pendamping belajar siswa memahami dengan baik semua tugas yang diberikan sehingga mereka perlu untuk belajar kembali. Terkait dengan situasi ini, sebagian ibu mengatakan mengontak guru untuk meminta penjelasan tugas, sebagiannya menunggu kesiapan saudara (kakak) untuk membantu sebagiannya mempelajari lewat internet. Dalam kaitan dengan internet ibu mengatakan akan mengikuti saja apa yang dijelaskan oleh internet tanpa harus mempelajari lebih lanjut informasi yang diperoleh. Dampaknya adalah tidak ada validasi informasi pengetahuan yang diakses dari internet. Satu hal yang paling penting adalah, tugas yang diberikan dapat diselesaikan terlepas dari anak paham dengan baik atu tidak.

Kesulitan yang dihadapi dalam proses belajar dari rumah ini tidak hanya berkait dengan materi belajar anak tetapi juga dengan situasi social keluarga, termasuk membagi waktu antara pekerjaan rumah dengan mendampingi anak belajar.

“ kesulitan terbesar saya adalah harus menggantikan tugas guru untuk beberapa orang anak. Anak saya 2 orang pada tingkat SD, kelas 5 dan kelas 2 dan 1 orang pada tingkat TK. Bagaimana mungkin saya bisa membantu secara maksimal, sedangkan pelajaran anak-anak Sd sekarang jauh berkembang dan saya tidak mengikuti perkembangan materi ajar tersebut pada waktu sebelumnya. Untuk belajar lagi dengan materi belajar anak yang berbeda-beda membuat saya merasa tidak mampu. Belum lagi anak belajar dengan orang tua suka banyak main dan manja-manjanya, tambah pusing kepala, daripada saya stress dan anak yang menjadi sasaran maka mending saya cari guru privat/les untuk mendampingi sekaligus mengajar anak. Kalau dengan guru les anak lebih disiplin disbanding dengan ibunya. Tetapi menjadi menambah biaya yang harus dikeluarkan

Dalam keadaan ini, sebagian ibu kecil/keluarga yang memiliki ekonomi tinggi justru mencari guru private dan meminta guru untuk membimbing dan mengajar anaknya. Dengan demikian maka semua tugas anak akan dibimbing langsung oleh guru private yang datang setiap hari sebagaimana belajar secara regular. Ibu hanya akan memantau sekedarnya proses pembelajaran anak Bersama guru privatenya.

Harus diakui, membimbing belajar siswa tingkat dasar bukanlah kegiatan yang mudah mengingat usia yang masih sangat muda dan kecenderungan untuk bermain sangat tinggi. Terlebih lagi pada anak yang masih berada pada tingkat kelas rendah, kelas 1-3 SD, masih 
Vol. 19, No. 2, 2020, Hal. 108 - 120

belum jauh berbeda dengan anak usia TK. Konsep learning by doing menjadi bagian penting yang tidak boleh diabaikan. Disisi semakin bertambah usia anak akan mengenal dunia di luar lingkup keluarga dan mulai membangun diri ketika terkait dengan relasi social lain baik di sekolah, kelompok social sebaya. Praktis akan terjadi perubahan fisik dan psikis kognitif anak yang tidak selalu patuh pada rutinitas dan aturan keluarga (Eccles:1999).

Membelajarkan anak masa pandemic Covid 19 ini hakikatnya membelajarkan anak pada kondisi khusus. Banyak aspek regularitas anak yang terpangkas dan terpaksa mengikuti pola yang dibangun. Belajar dari rumah mau tidak mau membangun situasi dan pengkondisian baru bagi anak dan ibu sebagai pendamping belajar. Situasi ibu yang semula lebih pada control pengulangan materi belajar yang diperoleh dari sekolah bergeser menjadi pendamping yang berperan sebagai control, fasilitator, motivator bahkan mengajar sebagaimana yang dilakukan seorang guru. Pada posisi ini, secara fenomenal tampak titik pentingnya keberdayaan perempuan secara akademik ( Khan,Yasmeen, Karim :2019, , ainiyah: 2017, Hill and King : 1995, Erni:2008) yang tidak saja akan berdampak pada ekonomi tetapi juga kesadaran social yang tentu akan memperbaiki kualitas hidup; keluarga. Dengan keberdayaan pendidikan juga ibu akan lebih fleksibel menghadapi situasi belajar dari rumah seperti sekarang. Kemauan untuk mempelajari ulang materi, mecari informasi yang terkait dengan materi, memahami situasi anak yang cenderung masih pada fase lebih banyak bermain, mengatasi kebosanan anak dengan berbagai cara menjadi inisiatif ibu untuk memenuhi ketercapaian tagihan belajar anak hanya akan muncul pada ibu yang terpelajar.

Namun, dalam situasi berdaya pendidikan, ibu sebagai pendamping belajar tampak masih menghadapi dilemma yang tidak sederhana dengan kegiatan BDR. Data Pendidikan ibu di atas menunjukkan masih terdapat ibu yang tidak tamat SMU sehingga kesulitan semakin meningkat jika harus mendampingi belejar anak di rumah. Dari seluruh responden sebagian besar mengatakan tidak bisa mendisiplinkan anak untuk belajar. Ketika harus belajar sesuai pembelajaran yang diberikan dari sekolah, anak hanya akan focus pada bentuk tugas yang diberikan dan segera mencari jawaban. Adakalanya guru meminta siswa untuk membaca buku terlebih dahulu sebelum menjawab pertanyaan, tetapi yang dilakukan siswa justru segera menjawab langsung jika sudah mengetahui jawabannya dan mencari di "google" ketika tidak mengerti sosal dan jawaban yang dikehendaki. Ketika tidak ada tugas berupa soal yang diberikan, siswa tetap belajar dengan cara membaca, menggambar atau kegiatan lain yang terkait dengan materi-materi pembelajaran di sekolah. Boleh dikatakan sejak belajar dari rumah, waktu bermain menjadi sangat banyak. Terlebih lagi ketika tidak boleh bermain ke luar rumah, teman tidak boleh datang, tidak boleh bepergian kecuali hal-hal penting. Tingkat 
Vol. 19, No. 2, 2020, Hal. 108 - 120

kebosanan siswa selama di rumah menjadi tinggi (medcom.id: 2020, Harianjogja.com :2020) belajar tidak intens sehingga bermain, menonton dan aktifitas non produktif banyak dilakukan. Lebih dari $50 \%$ ibu ataupun pendamping belajar dengan cara sambil mengerjakan pekerjaan rumah tangga sehingga control terhadap proses belajar anak juga menjadi tersambilkan saja. Dampaknya tidak banyak yang bisa dilakukan karena focus lebih pada pekerjaan rumah tangga yang sedang dikerjakan. Dalam banyak hal pekerjaan yang dilaksanakan dengan cara tidak terfokus dipastikan tidak akan mendapatkan hasil yang baik. Demikian pula dengan Pendidikan ataupun proses belajar anak di rumah.

Sama sekali tidak dapat ditolak bahwa faktanya pendampingan belajar anak dari rumah menjadi pekerjaan tambahan ibu setelah pekerjaan rumah tangga terselesaikan. Pekerjaan rumah tangga yang selama ini tidak dianggap bukan pekerjaan karena tidak mendatangkan penghasilan finansial sehingga sering diremehkan dan diangap sepele menghabiskan waktu ibu lebih dari jam kerja normal di luat rumah . Ibu rumah tangga yang hanya mengurusi rumah tangga tidak dianggap bekerja sehingga banyak hal yang berkait dengan tugas-tugas tambahan yang secara aksidental harus dilaksanakan di rumah secara langsung akan dibebankan pada ibu. Pekerjaan ibu di rumah tangga yang dianggap bukan "pekerjaan" (unpaid work) secara tidak langsung meletakkan posisi pekerjaan tersebut pada posisi stag, tidak membutuhkan keahlian, pengembangan, maupun inovasi telah menempatkan ibu pada posisi stag pula. Disisi lain, terdapat ibu yang memiliki pekerjaan lain diluar rumah sehinga harus membagi waktu dengan pekerjaan rumah. Banyak riset yang menjelaskan posisi rumit perempuan (ibu) yang berada di tengah persimpangan antara profesionalisme kerja di luar dan pekerjaan rumah tangga (Arora, Arango, Burkart, Chirinda, Twyman :2017, Mills :2015). Pekerjaan yang ada ditambah dengan mendampingi anak belajar dari rumah ini semakin menambah beban ibu yang tentu mempengaruhi kesehatan (Doyal:1995). Pilihan pekerjaan antara bekerja di luar rumah dengan hanya dirumah mengerjakan pekerjaan rumah hakikatnya tidak lepas dari tekanan situasi yang harus dikelola dengan baik (Jewel :2016)

“.. ketika anak malas, lamban, terkesan tidak perduli dengan belajar dan pengerjaan tugas dari sekolah, saya lebih memilih, membujuk, diam dan menunggu. Terkadang membiarkan anak sampai siap untuk belajar. Saya mengerti jika terdapat ibu yang menjadi stress akibat adanya belajar dari rumah ini, bahkan terkadang ibu jadi emosi. Bayangkan saja pekerjaan rumah yang gak selesai-selesai, beberapa orang anak yang harus didampingi belajar, belum lagi "perangai” anak yang macam-macam. Kalau keluarganya (ayah-suami) paham dengan kondisi, aman-aman sajalah rumah. Tetapi ada yang tidak mau perduli 
Vol. 19, No. 2, 2020, Hal. 108 - 120

samasekali, yang penting semua urusan di rumah tampak selesai dengan baik. Termasuk urusan belajar dan tugas-tugas anak dari sekolah".

Secara sosial kesulitan yang dihadapi ibu dalam masa belajar dari rumah tidak bisa dilepaskan begitu saja dari pola relasi social yang ada. Bahwa sekolah sangat jarang mengkomunikasikan perkembangan emosional dan akademik anak kepada orang tua. Padahal komunikasi oarng tua dan guru (sekolah) sangat penting dalam membangun sinergitas perlakuan terhadapa anak(Pusitaningtyas:2016) Disamping itu, dengan beban kerja rumah dan bahkan kerja kantor sebagian orang tua/ ibu menyerahkan saja pendidikan anaknya pada sekolah. Dalam kaitan ini, sekolah fullday mendajdi pilihan karena dianggap mampu membelajarkan siswa sekaligus menanamkan nilai karakter pada siswa (sari, wardani, noviani: 2017). Over trusted orang tua pada sekolah adakalnya dengan sengaja telah membuat abai akan perkembangan sosio -emosional yang ada. Akibat yang dirasakan adalah ketika terjadi kondisi khusus, orang tua terkesan mengalami kesulitan besar memandu anaknya untuk belajar dari rumah.

Pada lain pihak, kesulitan mendampingi anak belajar dari rumah semakin terasa akibat adanya pemilahan jelas antara pekerjaan laki-laki dan perempuan (ayah dan ibu) menjadi preseden tersendiri yang menghadirkan kerumitan social menghadapi situasi belajar dari rumah masa pandemic covid 19 ini. Mendampingi anak belajar terkesan tugas ibu karena dianggap lebih dekat dengan anak, ibu "tidak bekerja" sehingga bisa lebih banyak membantu anak belajar.

“.. menemani anak belajar murni saya, karena ayahnya bekerja. Walaupun ada masanya kerjanya dari rumah tetapi tetap dia bekerja dan sibuk dengan pekerjaannya. Praktis sebagai ibu rumah tangga anak menjadi tanggung jawab ibu untuk menemaninya belajar. Ya.. disambil-sambil antara pekerjaan rumah dan mendampingi belajar. Jika tidak didampingi anak tidak akan belajar. Lebih banyak main game dan menonton. Untuk belajar dia menunggu sampai ditemani".

Harus diakui bahwa pada masyarakat umum pola relasi gender dalam rumah tangga belum memiliki perimbangan yang cukup. Antara pekerjaan productive dan reproductive di rumah secara budaya masih terpilah antara laki-laki dan perempuan. Perempuan pada umumnya menganggap bahwa anak adalah tanggung jawab utama dirinya, sama halnya dengan pekerjaan rumah lainnya, kendati harus mengerjakan pekerjaan professional lain di luar rumah. Terutama perempuan yang berada di wilayah pedesaan, stigma pekerjaan rumah 
Vol. 19, No. 2, 2020, Hal. 108 - 120 tangga yang melekat pada perempuan tidak dengan sendirinya lepas dengan mengerjakan pekerjaan di luar yang memiliki penghasilan secara finansial. Banyak riset yang menyebutkan bahwa pekerjaan ekonomis dan keikutsertaan perempuan dalam usaha ekonomis tidak lebih dari mendukung suami dalam memenuhi kebutuhan (Arsal, Basri, Tono:2017). Stigma social ini juga telah mengakar termasuk dalam diri perempuan sendiri sehingga jika ditemui permasalahan khusus berkait dengan keluarga terutama anak maka ibu sebagai perempuan utama dalam rumah akan segera mengambil peran optimal.

\section{SIMPULAN}

Penelitian ini menegaskan situasi rumit yang dihadapi ibu dalam mendampingi anak selama belajar dari rumah pada masa pendemi covid 19. Ketertinggalan ibu dengan muatan pelajaran, keberagaman kecenderungan dan gaya belajar anak sehingga terkadang harus berperan sebagai "guru", padatnya waktu kerja rumah dan professional lain membuat kesulitan dalam membagi waktu. Dampaknya pendampingan belajar tidak dapat dilakukan secara optimal. Situasi "ruwet" ini setidaknya dapat ditilik dari 3 hal yang selama ini sering terabaikan yakni; keberdayaan akademik ibu/pendamping, kurangnya komunikasi sekolah dengan orang tua terkait perkembangan sosio-emosional dan akademik siswa dan terbebannya ibu dengan seluruh urusan di rumah sehingga ketika anak harus belajar dari rumah sebagai pengganti belajar di sekolah maka semakin bertambah beban kerja yang harus dikerjakan., wallahu a'lam 


\section{REFERENSI}

Abdullah, Irwan., (1997) Sangkan Paran Gender, Pusat penelitian Kependudukan UGM, , Kemendiknas, Surat Edaran No. 15 tahun 2020 tentang Pedoman Penyelennggaraan Belajar dari Rumah.pustaka pelajar, Yogyakarta

Ainiyah, Qurrotul., Urgensi Pendidikan Perempuan Dalam Menghadapi Masyarakat Modern, „Halaqa: Islamic Education Journal 1 (2), Desember 2017, 45-56 ISSN 2503 - 5045 (online) Journal Homepage: http://ojs.umsida.ac.id/index.php/halaqa

Arora, Dikhsa, Jacobo Arango, Stefan Burkart, Ngonidzashe Chirinda, Jennifer Twyman, (2017), Gender [im]balance in productive and reproductive labor among livestock producers in Colombia: Implications for climate change responses Findings from a qualitative field study in the municipality of Patía in Cauca region of Colombia, CGIAR, Research Program on climate change, agriculture and food security (CCAFS)

Arsal, Thriwaty., Muhammad Basri, Sumartono Tono,(2017) Bakul: Contribution of Rural Women to Family Economy through Informal Sector Activities, Komunitas: International Journal of Indonesian Society and Culture 9(1)

Doyal, Lesley., What makes women sick, gender and political economy of health, (1995), McMillan Press Ltd, London

Eccles, Jacquelynne S., The Development of Children Ages 6 to 14 ,The Future of Children WHEN SCHOOL IS OUT Vol. 9 • No. 2 - Fall 1999

Erni, Sukma., Perempuan dan pendiidkan, marwah Jurnal perempuan, agama dan gender, Vol VII, NO 2, edisi juli-desember 2008

Erni, Sukma, Tadarus Ramadhan, FB, Magister PGMI UIN Suska Riau

Fakih, Mansur., 2008, analisis gender dan traformasi social, pustaka pelajar offset, Yogyakarta.

Hill, M. Anne., (Queens College), CUNY Elizabeth M. King, (The World Bank), women's education and economic well-being, Feminist Economics 1(2), 1995, 21-46 13545701 ( IAFFE 1995)

Jewell, Julie P., Perceptions of Mothers' Work Choices, (2016), Journal of Management and Strategy Vol. 7, No. 1, URL: http://dx.doi.org/10.5430/jms.v7n1p1 
Khan $(\mathrm{PhD})^{*}$, Farah., Ghazala Yasmeen $(\mathrm{PhD}) \dagger$, and Nayab Karim $\ddagger$

PUTAJ (2019), Humanities and Social Sciences Vol. 26, No.1 (January-June), 13, Role of Female Education in National Economic Development of Pakistan,

Mallers,M.H, Neupert,S.D., Charles, S.T., \& Almaeda, D.M.,(2010) Perceptions of childhood relation with mother and father, daily emotional and stressor experiences in adulthood, journal of developmental psychology, vol.46, no. 06, 1651-1661

Mills, Maura J., Gender and the Work Family Experience, An Intersection on twoo domain, (2015), Springer, NewYork

Nixon, E (2010). Children's perspective on parenting style and discipline : A Developmental approach. Dublin, the national children's strategy research series

Pusitaningtyas, Anis., (2016), Pengaruh komunikasi orang tua dan guru terhadap kreativitas siswa, Proceeding of ICECRS, 1 (2016) 935-942 ISSN. 2548-6160 International Seminar on Generating Knowledge Through Research, UUM-UMSIDA, 25-27 October 2016, Universiti Utara Malaysia, Malaysia. Available online: http://ojs.umsida.ac.id/index.php/icecrs Article DOI: http://dx.doi.org/10.21070/picecrs.v1i1.632, 935

Santrock, JW. (2011), Child Development, Thirteenth edition, McGrawHill, New York

Sari, Prima Ratna. , Dewi Kusuma Wardani, Leny Noviani,(2017), Implementasi full day school (sekolah sehari penuh) sebagai best practice (latihan terbaik) dalam pendidikan karakter di sma negeri 1 sragen, bise; jurnal pendidikan bisnis dan ekonomi, vol.3 no. 2

Suhertina, Darni, (2018) Fenomena Double Burden Perempuan Pemulung Muslim dalam Pengelolaan Ekonomi Keluarga, Marwah: Jurnal Perempuan, Agama dan Jender ( $\mathrm{p}$ ISSN: 1412-6095| e-Issn: 2407-1587 Vol. 17, No. 2, Hal. 179-190

Tarenji, 2012, https://www.researchgate.net/publication/318876910

Medcom. Id (2020), FSGI Sebut Siswa Bosan Belajar Daring, 1 April, 20:19

Harianjogja.com, Gawat hasil Riset UGM ; Banyak Siswa Bosan dengan Belajar Online, 06 Agustus 2020: 12;07 